\title{
HUBUNGAN PERSEPSI TERHADAP LABEL PERINGATAN BAHAYA ROKOK PADA KEMASAN ROKOK DENGAN KEBIASAAN MEROKOK DI KELURAHAN NUSUKAN KECAMATAN BANJARSARI KOTA SURAKARTA
}

\author{
Diyono $^{1}$, Dewi Anggraeni ${ }^{2}$
}

\begin{abstract}
Background: This study was based on observations carried out because the researcher amount or number of smokers in the community is still quite high. This condition is very ironic because then our government through the health department conduct anti-smoking campaigns, but in fact has not been able to decrease the number of smokers significantly.

Objective: to analyze the relationship between the perception of warning labels cigarette with smoking.

Method: Research design correlation. The study population throughout the Village community Nusukan Banjarsari District of Surakarta who have the habit of smoking, making approximately 100-150 residents. The sample size of 100 respondents by using cluster random sampling technique sampling. Data were analyzed with Chi - Square with p: 0.005 SPSS 16 series.

Results: (1) $90 \%$ pay attention to warning labels cigarette and only $10 \%$ who do not pay attention (2) Label the dangers of smoking in pictures more attention that is $79 \%$ more than the writing that is $21 \%$ (3) label the dangers of cigarettes are perceived fear by $51 \%$ of the people and perceived unusual or fear as much as $49 \%$ (4) the smoking habit lightweight category $6 \%$, the moderate category was $56 \%$ and having a heavy smoking habit of $38 \%$ of respondents.

Conclusion: There was a significant correlation between the perception of warning labels cigarette with smoking $(P=0.000)$, with a moderate degree of correlation $(r=0.391)$.
\end{abstract}

Keyword: Perception, Hazard Warning Label Cigarette Smoking Habit

\section{PENDAHULUAN}

Penelitian ini dilakukan karena berdasar pengamatan peneliti jumlah atau angka perokok di masyarakat masih cukup tinggi. Kondisi ini kontradiktif dengan begitu gencarnya pemerintah melalui departemen kesehatan melakukan kampanye anti rokok, namun pada kenyataannya belum dapat menurunkan jumlah perokok secara signifikan. Hasil riset kesehatan dasar (Riskesdas) tahun 2010 menyebutkan hampir $34,07 \%$ penduduk Indonesia yang berusia di atas 10 tahun adalah perokok. Hasil laporan badan kesehatan dunia (World Health Organization/WHO) tahun 2008 bahkan menempatkan Indonesia pada posisi penghisap rokok terbanyak ketiga di dunia, dengan jumlah perokok mencapai 6,2 juta dari 1,1 milyar perokok di dunia atau sebesar $32,2 \%$ penduduk. Permasalahan rokok merupakan masalah yang serius dan perlu ditanggulangi bersama. Hal ini berdasarkan kepada buruknya pengaruh rokok pada kesehatan dan kesejahteraan baik pada perokok sebagai individu khusus maupun negara Indonesia secara umum. 
(Lenardi, 2014). Upaya untuk menyadarkan para pecandu rokok untuk meninggalkan rokok memang tidak mudah. Banyak hal yang telah dilakukan, bahkan yang terkini dan menjadi bahan perbincangan saat ini yaitu tertera gambar bahaya atau penyakit-penyakit yang disebabkan oleh merokok yang sangat mengerikan pada kemasan rokok. Akan tetapi gambar mengerikan tersebut belum mempunyai dampak yang signifikan dalam menurunkan kebiasaan merokok. (Permatasari, 2015) Berdasar pengamatan yang peneliti lakukan dewasa ini masih banyak masyarakat bahkan pada usia yang masih sangat muda sudah menjadi pecandu rokok. Beberapa dari mereka mengatakan tidak peduli dengan peringatan bahaya rokok yang ada di kemasan rokok baik berupa tulisan maupun gambar. Ada sebagian dari mereka bahkan menganggap gambar peringatan bahaya rokok yang ada di dalam kemasan rokok sebagai gambar yang lucu dan tidak menakutkan. Namun demikian sampai saat ini belum ada penelitian secara rinci tentang kaitan persepsi masyarakat terhadap peringatan bahaya merokok dengan kebiasan merokok. Berdasarkan uraian tersebut, maka peneliti memandang perlu untuk melakukan penelitian yang berjudul "Hubungan Persepsi Tentang Label Peringatan Bahaya Rokok Dengan Kebiasaan Merokok Pada Masyarakat."

\section{TUJUAN PENELITIAN}

Penelitian ini bertujuan untuk menganalisis ada tidaknya hubungan antara persepsi tentang label peringatan bahaya rokok pada kemasan rokok dengan kebiasaan merokok.

\section{METODE PENELITIAN}

Jenis penelitian ini adalah penelitian analitik dengan desain korelasi untuk mengetahui hubungan antara persepsi masyarakat terhadap label peringatan bahaya rokok sebagai variabel bebas dan kebiasaan merokok sebagai variabel terikat.

\section{POPULASI, SAMPEL DAN TEHNIK SAMPLING}

Populasi penelitian adalah seluruh masyarakat Kelurahan Nusukan Kecamatan Banjarsari Kota Surakarta yang mempunyai kebiasaan merokok. Dari hasil survei awal jumlah perokok aktif yang ada di daerah tersebut sekitar $100-150$ warga.

Besar sampel yang peneliti ambil adalah 100 responden. Jumlah tersebut peneliti ambil berdasar tabel Krecjie.

Teknik sampling yang peneliti gunakan adalah cluster random sampling, yaitu dari $14 \mathrm{RW}$ peneliti ambil secara acak sebanyak $10 \mathrm{RW}$ dan setiap RW peneliti ambil 10 perokok aktif.

\section{HASIL PENELITIAN}

Persepsi Terhadap Label Peringatan Bahaya Rokok

Tabel 1

Distribusi Frekwensi Perhatian

Masyarakat Kelurahan Nusukan

Banjarsari Kota Surakarta Terhadap Label Bahaya Merokok

\begin{tabular}{ccc}
\hline $\begin{array}{c}\text { Perhatian } \\
\text { Masyarakat } \\
\text { Terhadap Label } \\
\text { Bahaya Rokok }\end{array}$ & $\mathrm{f}$ & $\%$ \\
\hline Memperhatikan & 90 & 90 \\
\hline Tidak & 10 & 10 \\
\hline Jumlah & 100 & 100 \\
\hline
\end{tabular}

Temuan penelitian sebagaimana ditunjukkan pada tabel 1. memperlihatkan bahwa pada dasarnya mayoritas masyarakat memperhatikan label bahaya rokok yang ada pada kemasan rokok, dimana $\quad 90 \% \quad$ responden memperhatikan dan hanya $10 \%$ yang tidak memperhatikan. 
Tabel 2

Distribusi Frekwensi Label Bahaya

Rokok yang Paling Diperhatikan oleh Masyarakat Kelurahan

Nusukan Banjarsari Kota Surakarta

\begin{tabular}{ccc}
\hline $\begin{array}{c}\text { Label Bahaya } \\
\text { Rokok yang Paling } \\
\text { Diperhatikan oleh } \\
\text { Masyarakat }\end{array}$ & $\mathrm{f}$ & $\%$ \\
\hline Gambar & 79 & 79 \\
\hline Tulisan & 21 & 21 \\
\hline Jumlah & 100 & 100 \\
\hline
\end{tabular}

Berdasar tabel 2 jelas menunjukkan bahwasanya masyarakat lebih memperhatikan label bahaya rokok dalam bentuk visual gambar atau foto yaitu $79 \%$ lebih banyak daripada tulisan yaitu $21 \%$.

Kebiasaan Merokok

Tabel 3

Distribusi Frekwensi Persepsi

Masyarakat Kelurahan Nusukan Banjarsari Kota Surakarta Terhadap Label Bahaya Rokok

\begin{tabular}{|c|c|c|}
\hline $\begin{array}{c}\text { Persepsi } \\
\text { Masyarakat } \\
\text { Terhadap Label } \\
\text { Bahaya Rokok }\end{array}$ & f & $\%$ \\
\hline Biasa & 49 & 49 \\
\hline Takut & 51 & 51 \\
\hline Jumlah & 100 & 100 \\
\hline
\end{tabular}

Tabel 3 menunjukkan walaupun selisihnya relatif sangat kecil yaitu $2 \%$, namun cukup membuktikan bahwa dengan adanya label bahaya rokok membuat masyarakat lebih banyak yang takut $(51 \%)$ daripada yang biasa atau tidak takut sebanyak (49\%).
Kebiasaan Merokok

Tabel 4

Distribusi Frekwensi Kebiasaan

Merokok Masyarakat Kelurahan

Nusukan Banjarsari Kota Surakarta

\begin{tabular}{ccc}
\hline Kebiasaan Merokok & $\mathrm{f}$ & $\%$ \\
\hline Ringan $(1-5)$ & 6 & 6 \\
\hline Sedang $(6-15)$ & 56 & 56 \\
\hline Berat $(>15)$ & 38 & 38 \\
\hline Jumlah & 100 & 100 \\
\hline
\end{tabular}

Kebiasaan merokok pada masyarakat khususnya pada area penelitian yaitu masyarakat kelurahan Nusukan Bajarsari Surakarta relatif masih tinggi, dimana yang mempunyai kebiasaan ringan yaitu merokok $1-5$ batang per hari menempati persentase paling sedikit yaitu hanya 6 atau 6 $\%$ responden, Sedangkan yang mempunyai kebiasaan merokok pada kategori sedang yaitu $6-15$ batang per hari mencapai $56 \%$ dan yang mempunyai kebiasaan merokok berat yaitu lebih dari 15 batang per hari masih cukup tinggi yaitu sebesar 38 atau $38 \%$ responden.

Tabel 5

Distribusi Frekwensi Penurunan

Kebiasaan Merokok Masyarakat

Kelurahan Nusukan Banjarsari Kota Surakarta

\begin{tabular}{ccc}
\hline $\begin{array}{c}\text { Penurunan } \\
\text { Kebiasaan } \\
\text { Merokok }\end{array}$ & $\mathrm{f}$ & $\%$ \\
\hline Menurun & 30 & 30 \\
\hline Tidak Menurun & 70 & 70 \\
\hline Jumlah & 100 & 100 \\
\hline
\end{tabular}

Tabel 5 memperlihatkan bahwa sebagian besar masyarakat menyatakan kebiasaan merokok setelah ada label peringatan bahaya merokok tidak menurun yaitu $70 \%$ lebih tinggi daripada yang menyatakan menurun yang hanya sebesar $30 \%$. 
Hubungan Persepsi Terhadap Label Peringatan Bahaya Rokok dengan Kebiasaan Merokok

Tabel 6

Tabel Tabulasi Silang Hubungan

Persepsi Terhadap Label Bahaya

Rokok dengan Kebiasaan Merokok

Masyarakat Kelurahan Nusukan

Banjarsari Kota Surakarta Tahun 2016

PERSEPSI * MEROKOK Crosstabulation

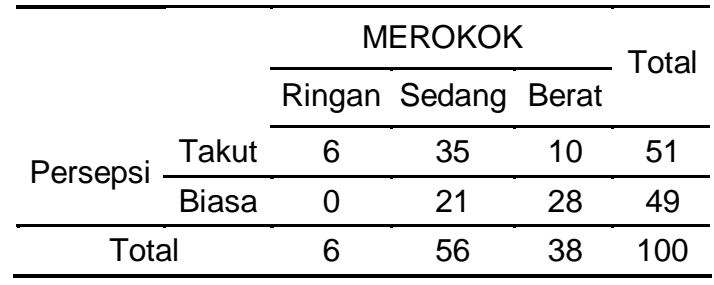

Sesuai tabel 6 terlihat bahwa jumlah responden yang mempunyai persepsi terhadap label peringatan bahaya merokok takut dengan kebiasaan merokok ringan sebanyak $6 \%$, sedang $35 \%$, dan kebiasaan berat $10 \%$. Adapun pada kelompok yang mempunyai persepsi biasa, yang mempunyai kebiasaan merokok ringan sebanyak $0 \%$, sedang $21 \%$, dan yang mempunyai kebiasaan merokok berat sebanyak $28 \%$. Sesuai tabel 4.6. terlihat bahwa jumlah responden yang mempunai persepsi terhadap label peringatan bahaya merokok takut dengan kebiasaan merokok ringan sebanyak $6 \%$, sedang $35 \%$, dan kebiasaan berat $10 \%$. Adapun pada kelompok yang mempunyai persepsi biasa, yang mempunyai kebiasaan merokok ringan sebanyak $0 \%$, sedang $21 \%$, dan yang mempunyai kebiasaan merokok berat sebanyak $28 \%$.
Tabel 7

Hasil Uji Chi Square Hubungan

Persepsi Terhadap Label Bahaya

Rokok dengan Kebiasaan Merokok

Masyarakat Kelurahan Nusukan

Banjarsari Kota Surakarta

Chi-Square Tests

\begin{tabular}{lccc}
\hline & Value & df & $\begin{array}{c}\text { Asymp. } \\
\text { Sig. (2- } \\
\text { sided) }\end{array}$ \\
\hline $\begin{array}{l}\text { Pearson Chi- } \\
\text { Square }\end{array}$ & $17.994^{\mathrm{a}}$ & 2 & .000 \\
\hline $\begin{array}{c}\text { Likelihood } \\
\text { Ratio }\end{array}$ & 20.693 & 2 & .000 \\
\hline $\begin{array}{c}\text { Linear-by- } \\
\text { Linear } \\
\text { Association }\end{array}$ & 17.811 & 1 & .000 \\
\hline N of Valid Cases 100 & & \\
\hline
\end{tabular}

Berdasar tabel 7 memperlihatkan nilai Pearson Chi Square adalah sebesar 0,000 . Nilai tersebut lebih kecil dari 0,05 yang menujukkan ada hubungan yang signifikan antara Persepsi Terhadap Label Bahaya Rokok dengan Kebiasaan Merokok Masyarakat Kelurahan Nusukan Banjarsari Kota Surakarta.

Tabel 8

Nilai Koefisien Kontigensi Hubungan Persepsi Terhadap Label Bahaya

Rokok dengan Kebiasaan Merokok Masyarakat Kelurahan Nusukan Banjarsari Kota Surakarta Symmetric Measures

\begin{tabular}{|c|c|c|}
\hline & Value & $\begin{array}{c}\text { Approx. } \\
\text { Sig. }\end{array}$ \\
\hline $\begin{array}{cc}\begin{array}{c}\text { Nominal } \\
\text { by }\end{array} & \text { Contingency } \\
\text { Nominal } & \text { Coefficient }\end{array}$ & .391 & .000 \\
\hline $\mathrm{N}$ of Valid Cases & 100 & \\
\hline
\end{tabular}

Sesuai tabel 8 di atas menunjukkan bahwa nilai koefisien kontigensi sebesar 0,391 yang menujukkan kekuatan hubungan Persepsi Terhadap Label Bahaya Rokok dengan Kebiasaan Merokok Masyarakat Kelurahan Nusukan Banjarsari Kota Surakarta adalah pada kategori cukup. 


\section{PEMBAHASAN}

Label Peringatan Bahaya Rokok

Menurut Depkes RI (2004) sebagimana dikutip oleh Aryani (2010) yaitu: "Rokok pada dasarnya merupakan pabrik bahan kimia berbahaya. Saat batang rokok terbakar, maka asapnya menguraikan sekitar 4000 bahan kimia dengan tiga komponen utama, yaitu: nikotin yang menyebabkan ketergantungan/adiksi; tar yang bersifat karsinogenik; karbon monoksida yang aktivitasnya sangat kuat terhadap hemoglobin sehingga kadar oksigen dalam darah berkurang; dan bahan-bahan kimia lain yang beracun. Oleh karena itu banyak negara mulai melakukan ratifikasi undang undang anti tembakau guna mengurangi dampak negatif rokok terutama terhadap kesehatan. Salah satu langkah nyata dari pelaksanaan ratifikasi tersebut adalah dengan melakukan kampanye bahaya rokok melalui tulisan, poster, dan yang terbaru adalah dengan memasang label bahaya merokok dalam bentuk tulisan dan gambar pada setiap kemasan rokok.

Indonesia saat ini memiliki 672 perusahaan atau industri produsen rokok, yang secara keseluruhan, memproduksi 3300 lebih merek rokok di Indonesia dan di luar negeri. Pada tahap awal setiap produsen rokok wajib mencantumkan label peringatan bahaya merokok dengan menyajikan lima bentuk peringatan bergambar. Gambar tersebut adalah gambar kondisi paru-paru yang terkena kanker paru-paru, Kemudian kondisi mulut yang terkena kanker mulut dan juga tenggorokan yang terkena kanker tenggorokan. Selain itu gambar perokok dan kematian, selain juga peringatan ancaman bahaya merokok kepada bayi. Pemberlakuan peraturan tersebut terhitung 18 bulan setelah pengesahan Peraturan Pemerintah No. 109 Tahun 2012, tentang
Pengamanan Bahan yang Mengandung Zat Adiktif Berupa Produk Tembakau Bagi Kesehatan. Dan peraturan tersebut memperkuat Undang-Undang Nomor 36 tahun 2009 tentang Kesehatan yang menyatakan dengan tegas bahwa tembakau mengandung zat adiktif yang menyebabkan sejumlah penyakit dengan jumlah besar di Indonesia. (Depkes RI, 2010)

Persepsi Terhadap Label Peringatan Bahaya Rokok

Tujuan utama pemerintah melalui departemen kesehatan mewajibakan setiap kemasan rokok harus diberikan label bahaya merokok adalah untuk merubah persepsi masyarakat bahwa rokok memang berbahaya untuk kesehatan. Label bahaya rokok dalam bentuk gambar tidak lain adalah untuk semakin memberikan pengetahuan masyarakat tentang bahaya merokok dalam bentuk visual atau tidak hanya tulisan, sehingga diharapkan masyarakat semakin perhatian terhadap bahaya rokok terhadap kesehatan.

Temuan penelitian sebagaimana ditunjukkan pada tabel 1 memperlihatkan bahwa pada dasarnya mayoritas masyarakat memperhatikan label bahaya rokok yang ada pada kemasan rokok, dimana $\quad 90 \% \quad$ responden memperhatikan dan hanya $10 \%$ yang tidak memperhatikan. Temuan tersebut paling tidak memberikan informasi bahwa masyarakat cukup berespon positip terhadap kampanye anti rokok atau anti tembakau yang dilaksanakan pemerintah melalui pemasangan label bahaya rokok pada kemasan rokok. Dengan adanya perhatian tersebut maka diharapkan dapat meningkatkan persepsi masyarakat tentang bahaya rokok. Menurut Leavitt (1978) sebagaimana dikutip oleh Sobur (2003) persepsi dalam arti sempit ialah penglihatan, 
bagaimana cara seseorang melihat sesuatu, sedangkan arti luas ialah pandangan atau pengertian, yaitu bagaimana seseorang memandang atau mengartikan sesuatu. Definisi lain dari persepsi adalah menurut Aryani (2010), yang mendefinisikan persepsi sebagai proses akhir dari pengamatan yang diawali oleh proses penginderaan, yaitu proses diterimanya stimulus oleh alat indra, lalu diteruskan ke otak, dan baru kemudian individu menyadari tentang sesuatu yang dipersepsikan. Sebagai hasil akhir dari suatu proses analisis penginderaan, maka persepsi dapat berupa keputusan akhir seseorang yang terwujud dalam bentuk pendapat, sikap, ataupun perilaku, seperti pendapat benar atau salah, positip atau negatif, takut atau berani, cemas atau biasa, perhatian ataupun apatis dan sebagainya. Sesuai definisi tersebut maka dengan adanya label bahaya rokok yang lebih visual melalui foto penyakit akibat rokok maka diharapkan masyarakat mempunyai pandangan yang berbeda berdasar hasil penglihatan atau pengideraan yang dilakukan. Hal ini juga dibuktikan dengan hasil penelitian, dimana masyarakat lebih memperhatikan label bahaya rokok dalam bentuk foto atau gambar daripada tulisan, sebagimana terlihat pada tabel 2.

Berdasar tabel 2 jelas menunjukkan bahwasanya masyarakat lebih memperhatikan label bahaya rokok dalam bentuk visual gambar atau foto yaitu $79 \%$ lebih banyak daripada tulisan yaitu $21 \%$. Seperti terlihat pada kemasan rokok, memang gambar visual yang saat ini wajib dipasang pada kemasan rokok adalah kondisi paru-paru yang terkena kanker paru-paru, mulut yang terkena kanker mulut dan juga tenggorokan yang terkena kanker tenggorokan. Selain itu juga gambar perokok dan kematian, peringatan ancaman bahaya merokok kepada bayi. Gambar - gambar tersebut dipasang sedemikian rupa sehingga jelas terlihat pada setiap kemasan rokok. Gambar - gambar tersebut terbukti lebih diperhatikan oleh masyarakat dibanding hanya sekedar tulisan. Dengan adanya label bahaya rokok pada kemasan rokok ternyata juga merubah persepsi masyarakat, sehingga semakin takut untuk merokok. Hal ini sesuai dengan temuan penelitian sebagaiman terlihat pada tabel 3 .

Tabel 3 menunjukkan walaupun selisihnya relatif sangat kecil yaitu $2 \%$, namun cukup membuktikan bahwa dengan adanya label bahaya rokok membuat masyarakat lebih banyak yang takut (51\%) daripada yang biasa atau tidak takut sebanyak (49\%). Menurut Aryani (2010), persepsi timbul secara spontan pada manusia, yaitu ketika seseorang menerima rangsangan atau stimulus dari luar maupun dalam dirinya. Persepsi merupakan sifat paling asli yang merupakan titik tolak dari terbentuknya sikap dan perilaku individu. Persepsi terkadang tidak mampu mewakili keseluruhan dari stimulus yang diterima, dan hanya sebagian yang dapat diingat dalam memori saja. Secara lebih rinci Sobur (2003) menjelaskan proses munculnya atau terbentuknya suatu persepsi melalui beberapa 6 (enam) tahapan yaitu proses menerima rangsangan, proses menyeleksi rangsangan, pengorganisasian stimulus, penafsiran, pengecekan, dan terakhir adalah proses reaksi. Tahap terakhir pada proses perseptual adalah bertindak sehubungan dengan apa yang telah diserap. Hal ini biasanya dilakukan jika seseorang berbuat suatu sehubungan dengan persepsinya. Misalnya, seseorang bertindak sehubungan dengan persepsi yang baik atau yang buruk yang telah dibentuknya. Lingkaran persepsi itu belum sempurna sebelum 
menimbulkan suatu tindakan. Tindakan ini tersembunyi dan bisa pula terbuka. Tindakan tersembunyi berupa tindakan atau sikap, sedangkan tindakan terbuka berupa tindakan yang atas sehubungan persepsi itu. Suatu gejala yang telah menarik perhatian sehubungan dengan tindakan tersembunyi ialah pembentukan kesan.

Kebiasaan Merokok

Hasil penelitian menujukkan secara umum kebiasaan merokok pada masyarakat masih cukup tinggi, seperti terlihat pada tabel 4, dimana kebiasaan merokok pada masyarakat khususnya pada area penelitian yaitu masyarakat kelurahan Nusukan Bajarsari Surakarta relatif masih tinggi, dimana yang mempunyai kebiasaan ringan yaitu merokok $1-5$ batang per hari menempati persentase paling sedikit yaitu hanya 6 atau 6 $\%$ responden, sedangkan yang mempunyai kebiasaan merokok pada katagori sedang yaitu $6-15$ batang perhari mencapai $56 \%$ dan yang mempunyai kebiasaan merokok berat yaitu lebih dari 15 batang perhari masih cukup tinggi yaitu sebesar 38 atau $38 \%$ responden. Menurut Husaini (2007), merokok adalah suatu kebiasaan (habituation) dan bukan satu ketergantungan (addiction). Ada perbedaan yang sangat mendasar antara kebiasaan (habituation) dan ketergantungan (addiction). Kebiasaan adalah membiasakan diri melakukan sesuatu karena ada bahan, bila menghentikan kebiasaannya maka akan muncul gejala-gejala psikis dari dalam dirinya.

Hubungan Persepsi Terhadap Label Peringatan Bahaya Rokok dengan Kebiasaan Merokok

Temuan penelitian sesuai yang terlihat pada tabel 5 menunjukkan bahwa jumlah responden yang mempunyai persepsi terhadap label peringatan bahaya merokok takut dengan kebiasaan merokok ringan sebanyak $6 \%$, sedang $35 \%$, dan kebiasaan berat $10 \%$. Adapun pada kelompok yang mempunyai persepsi "biasa", yang mempunyai kebiasaan merokok ringan sebanyak $0 \%$, kebiasaan sedang sebanyak $21 \%$, dan yang mempunyai kebiasaan merokok berat sebanyak $28 \%$. Data tersebut menunjukan proporsi masyarakat yang mempunyai kebiasaan merokok pada kategori sedang dan berat adalah pada kelompok masyarakat yang mempunyai persepsi "biasa" terhadap label peringatan bahaya merokok yaitu sebesar $28 \%$ pada kategori kebiasaan berat dan $21 \%$ pada kebiasaan merokok sedang, dan yang mempunyai kebiasaan merokok pada kategori ringan tidak ada atau $0 \%$. Didukung dengan hasil uji Chi Squre nilai $p=0,000$ menujukkan bahwa ada hubungan yang signifikan antara persepsi terhadap label peringatan bahaya rokok dengan kebiasaan merokok. Menurut Sobur (2003), menjelaskan proses munculnya atau terbentuknya suatu persepsi melalui 6 (enam) tahapan yaitu proses menerima rangsangan, proses menyeleksi rangsangan, pengorganisasian stimulus, penafsiran, pengecekan, dan terakhir adalah proses reaksi. Tahap terakhir pada proses perceptual adalah bertindak sehubungan dengan apa yang telah diserap. Hal ini biasanya dilakukan jika seseorang berbuat suatu sehubungan dengan persepsinya. Misalnya, seseorang bertindak sehubungan dengan persepsi yang baik atau yang buruk yang telah dibentuknya. Lingkaran persepsi itu belum sempurna sebelum menimbulkan suatu tindakan. Tindakan ini tersembunyi dan bisa pula terbuka. Tindakan tersembunyi berupa tindakan atau sikap, sedangkan tindakan terbuka berupa 
tindakan yang atas sehubungan persepsi itu. Suatu gejala yang telah menarik perhatian sehubungan dengan tindakan tersembunyi ialah pembentukan kesan. Proses persepsi tersebut terbukti secara empiris sesuai hasil penelitian yang menunjukkan bahwa setelah pada kemasan rokok diberikan label peringatan bahaya merokok, ternyata masyarakat terangsang atau terstimulus untuk melihat dan membaca, kemudian terjadi pengorganisasian, penafsiran dan pada akhirnya muncul reaksi takut atau biasa.

Sesuai hasil penelitian dari label peringatan bahaya merokok yang ada pada setiap kemasan rokok, yang paling diperhatikan oleh masyarakat adalah gambar atau foto penyakit akibat kebiasaan merokok. Dengan adanya gambar tersebut, kemudian diproses dan dipersepsikan oleh masyarakat dan kemudian muncul reaksi takut untuk merokok. Namun demikian nilai hubungan yang hanya sebesar 0,391 yang berarti tingkat hubungan pada kategori cukup, menunjukkan walaupun ada hubungan persepsi terhadap label peringatan bahaya rokok dengan kebiasaan merokok, namun tingkat hubungan relatif cukup. Hal ini dibuktikan dari data hasil penelitian, dimana walaupun masyarakat memperhatikan label bahaya rokok pada kemasan rokok, dan yang mempunyai persepsi takut lebih banyak daripada yang mempunyai persepsi biasa, namun belum membuat masyarakat menurunkan kebiasaan merokok secara drastis. Data menunjukkan masyarakat yang menyatakan kebiasaan merokok tidak turun relatif masih cukup besar yaitu $30 \%$. Hal ini juga didukung selisih antara masyarakat yang mempunyai persepsi takut dengan yang mempunyai persepsi biasa adalah sangat kecil yaitu hanya $2 \%$, dimana yang mempunyai persepsi takut sebesar $51 \%$, dan yang mempunyai persepsi biasa sebanyak $49 \%$.

Hasil ini senada dengan hasil penelitian terdahulu yang dilakukan oleh Kurniadi (2005) yang menyimpulkan terdapat hubungan positif antara sikap terhadap label peringatan bahaya merokok pada kemasan rokok dengan intensi berhenti merokok. Penelitian lain yang juga mendukung hasil penilitian ini adalah penelitian dari Dewi dan Damayanti (2008), yang menyimpulkan bahwa ada perbedaan yang signifikan persepsi masyarakat terhadap label bahaya rokok antara tulisan dengan gambar. Kedua penelitian tersebut walaupun dengan metode dan subyek yang berbeda, namun secara umum memberikan bukti bahwa label peringatan bahaya merokok yang ada pada kemasan rokok mempunyai hubungan dengan sikap, persepsi, dan kebiasaan merokok. Namun demikian yang patut menjadi perhatian dari penelitian ini adalah, walaupun pada kemasan rokok sudah diberikan atau dicantumkan peringatan bahaya rokok baik tulisan maupun dengan gambar yang mengerikan dan mempunyai hubungan dengan kebiasaan merokok, namun hubunganya belum kuat, sehingga relatif belum berdampak besar terhadap penurunan kebiasaan merokok pada masyarakat

\section{KESIMPULAN}

Kesimpulan yang diperoleh dari penelitian ini adalah :

1. $90 \%$ responden memperhatikan label peringatan bahaya rokok dan hanya $10 \%$ yang tidak memperhatikan

2. Label bahaya rokok dalam bentuk gambar lebih banyak diperhatikan yaitu $79 \%$ lebih banyak daripada tulisan yaitu $21 \%$

3. Label bahaya rokok dipersepsikan takut oleh $51 \%$ masyarakat dan dipersepsikan 
biasa atau tidak takut sebanyak $49 \%$

4. Kebiasaan merokok kategori ringan $6 \%$, katagori sedang sebanyak $56 \%$ dan yang mempunyai kebiasaan merokok berat sebesar 38\% responden

5. Ada hubungan yang signifikan antara persepsi tentang label peringatan bahaya rokok pada kemasan rokok dengan kebiasaan merokok $(P=0,000)$, dengan tingkat hubungan cukup $(r=0,391)$

\section{SARAN}

Beberapa saran yang dapat peneliti munculkan yaitu :

1. Label peringatan bahaya rokok pada kemasan rokok sebaiknya lebih banyak dalam bentuk gambar karena lebih diperhatikan oleh masyarakat

2. Perlu dipikirkan untuk mencari metode kampanye anti rokok yang lebih interaktif, misalnya dengan penggunaan audiovisual, diskusi peergoup dan sebagainya

3. Sebagai tindak lanjut hasil penelitian ini, maka ke depan perlu kiranya dilakukan penelitian tentang cara menurunkan kebiasaan merokok dengan berbagi macam pendekatan

\section{DAFTAR PUSTAKA}

Aryani, Ratna. 2010. Kesehatan Remaja Problem dan Solusinya. Salemba Medika, Jakarta.

Caldwell, Ernest. 2009. Berhenti Merokok. Pustaka Polpuler, Yogyakarta.

Depkes RI. 2010. Perilaku Merokok Masyarakat Indonesia. Infodatin : Pusat Data dan Informasi Kementerian Kesehatan Republik Indonesia. ISSN :2442.7659. Jakarta.
Dewi, Nina Candra dan Rita Damayanti. 2008. "Perbedaan Persepsi Gambar Peringatan Bahaya Merokok antara Masyarakat Jakarta dan Cirebon". URL: http;//jurnalkesmas.ui.ac.id/ind ex.php/kesmas/article/view/23 3 .. Diakses pada tanggal 30 Desember 2015.

Husaini, Aiman. 2007.Tobat Merokok Rahasia dan Cara Empatik Berhenti Merokok. Alih Bahasa Sari Narulita, Pustaka liman, Depok.

Kurniadi, Baskoro. 2005. "Hubungan antara sikap terhadap label peringatan bahaya merokok pada kemasan rokok dengan intensi berhenti merokok". URL:

http://psychology.uii.ac.id/imag es/stories/jadwal_kuliah/naska h-publikasi-00320026.pdf,.

Diakses pada tanggal 30 Desember 2015.

Lenardi, Melissa. 2014. "Label Visual Peringatan Pada Bungkus Rokok : Upaya Mutakhir Penekanan Angka Perokok di Indonesia". URL: http://www.academia.edu/7729 774/. Diakses pada tanggal 29 November 2015.

Sobur, Alex. 2003. Psikologi Umum Dalam Lintasan Sejarah. CV Pustaka Setia, Bandung

1 Dosen AKPER Panti Kosala Surakarta

2 Mahasiswa AKPER Panti Kosala Surakarta 